\title{
УДК 629.463.32-047.58
}

\author{
М. В. ПАВЛЮЧЕНКОВ ${ }^{1 *}$ \\ ${ }^{1 *}$ Каф. «Будівельна механіка та гідравліка», Українська державна академія залізничного транспорту, пл. Фейєрбаха, 7 , \\ Харків, Україна, 61500, тел. +38 (057) 73010 70, ел. пошта misha_83@ukr.net
}

\section{РАЦІОНАЛІЗАЦІЯ КОНСТРУКЦІї ОПОРНИХ ПРИСТРОЇВ ВАГОНІВ-ЦИСТЕРН ДЛЯ РІДКИХ ВАНТАЖІВ}

Мета. Удосконалення конструкції вагонів-цистерн для перевезення рідких вантажів за рахунок нових технічних рішень консольних опорних пристроїв і зниження їх матеріалоємності. Методика. Для вирішення поставленої задачі виконано дослідження для пошуку оптимальної конструкції опорного пристрою. На першому етапі зроблено патентно-бібліографічний аналіз технічних рішень, виявлено переваги й недоліки конструкцій, а також запропоновано нові їх варіанти, визначена найефективніша 3 них. На наступному етапі для визначення іï оптимальних параметрів складено функцію цілі, введено обмеження; отримано апроксимацію функцій цілі та обмежень у вигляді поліномів. На третьому етапі запропоновано чисельну реалізацію оптимізації функції та визначено оптимальні параметри конструкції графічним методом. Результати методів співпали. Результати. Серед запропонованих варіантів визначено найбільш ефективну конструкцію опорного пристрою, визначено його оптимальні геометричні розміри. Наукова новизна. Виконано математичний опис задачі оптимізаційного проектування за критерієм мінімальної матеріалоємності опорного пристрою вагона-цистерни та використано його для удосконалення конструкції. Для вирішення задачі оптимізаційного проектування використано чисельний та графічний методи. Практична значимість. Розроблено розрахункові скінченно-елементні моделі вагона-цистерни з різними конструктивними виконаннями консольних опорних пристроїв, які дали змогу оцінити НДС конструкції.

Ключові слова: вагони-цистерни; котел; консольний опорний пристрій; вантажопідйомність; підкріплюючий елемент; еквівалентне напруження; функція цілі; узагальнена математична модель

\section{Вступ}

Вагони-цистерни є одним 3 масових типів залізничного рухомого складу, які успішно застосовуються для перевезення наливних, пилоподібних, тверднучих вантажів і газів. Найбільш поширеними $є$ нафтобензи-нові цистерни. Умови експлуатації транспортних засобів висувають підвищені вимоги до міцності існуючих і нових конструкцій цистерн.

Дослідження [2, 6] свідчать, що напруження зумовлені дією опорного тиску, складають $70 \ldots 90 \%$ від максимальних напружень, які виникають в котлі цистерни. Упродовж тривалого часу експлуатації нафтобензинових цистерн були виявлені найбільш слабкі місця в їх конструкції у вигляді відмов, пов'язаних з течею і деформацією котлів, тріщинами в елементах рами та ін. Як зображено на рис. 1, несправності, пов'язані з течею котла в опорній зоні, складають 45,5 \% від усіх пошкоджень вагона $[15,16,18]$.

\section{Мета}

Метою роботи є удосконалення конструкції вагонів-цистерн для перевезення рідких вантажів за рахунок нових технічних рішень консольних опорних пристроїв і зниження їх матеріалоємності.

\section{Методика}

В цей час в конструкції вагонів практично повністю використаний простір габариту по ширині та висоті, тому подальше збільшення об'єму кузова можливо лише за рахунок збільшення його довжини, що призводить до збільшення тари вагона та до зменшення вантажопідйомності при збереженні осьового навантаження

$$
P \leq q_{o} m_{o}-T ; P \leq q_{n} L-T,
$$

де $P$ - вантажопідйомність вагона; $q_{o}$ - допустиме осьове навантаження вагона; $m_{o}-$ кількість осей вагона; $T$ - тара вагона; $q_{n}$ - допустиме погонне навантаження вагона; $L$ - довжина вагона по осях зчеплення.

(C) М. В. Павлюченков, 2014 

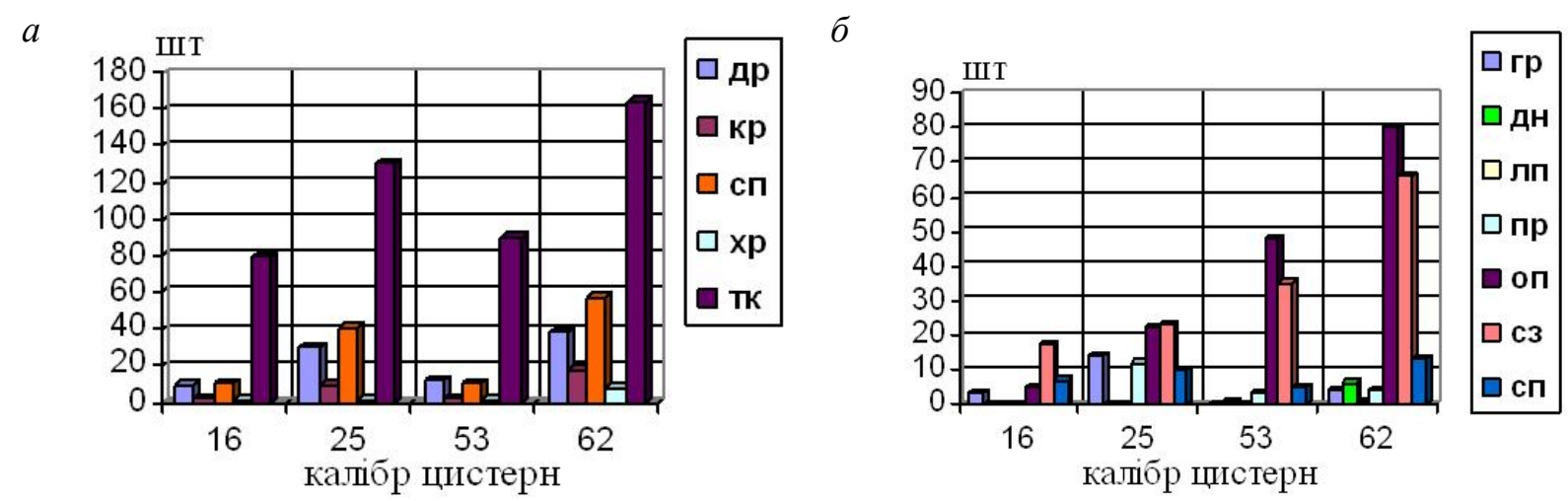

Рис. 1. Розподілення пошкоджень за типами для калібрів:

$a$ - всі пошкодження; $\sigma$ - теча котла; др - будь-яка неконкретизована несправність; кр - несправність кришки; сп - несправність зливного прибору; хр - несправність хребтової балки; тк - будь-яка теча котла; гр - теча в зоні горловини; теча в зоні днища; лп - теча в зоні фасонних лап; пр - будь-яка неконкретизована теча; оп - теча в опорній зоні; сз, сп - теча в зоні зливного пристрою та при його несправності

Оскільки $q_{o} m_{o}=$ const, $q_{n} L=$ const, тому подальше збільшення вантажопідйомності можливе лише за рахунок зменшення тари вагона.

Внесенням конструктивних змін, які спрямовані на перерозподіл навантажень та напружень в небезпечних зонах, може бути досягнутий ефект зниження максимальних напружень, а за рахунок цього і зниження металоємності.

У зв'язку з цим досить ефективним засобом зменшення концентрації напружень у найбільш напружених зонах оболонкових конструкцій $\epsilon$ застосування різного роду підкріплюючих елементів. Це пояснюється високою змінністю локального граничного ефекту та вигинистого стану у взаємодії оболонки і підкріплюючого елемента, яка дає певні можливості для перерозподілу місцевих напружень [10].

Для вирішення поставленої задачі виконано дослідження з пошуку оптимальної конструкції опорного пристрою. На першому етапі виконано патентно-бібліографічний аналіз технічних рішень $[7,9]$, виявлено переваги і недоліки та запропоновано нові варіанти конструкцій [11]. На основі досвіду $[1,12,13]$ побудовані CEM вагонів-цистерн з різними конструкціями опорних пристроїв.

Консольна опора першого варіанта зображена на рис. 2. Опорні елементи 1 підкріплено діафрагмами 2 і ребрами жорсткості 3. Діафрагми 2 сполучені між собою похилими листами 4 і встановлені на шкворневому листі 5 .

Варіант 2 опорної конструкції зображено на рис. 3. Тут опорні елементи 1 підкріплено діаф- рагмами 2 , які розташовані уздовж твірної котла, і спираються на шкворневий лист 3 . У цій схемі подовжні діафрагми 2 сполучені між собою стержнями.

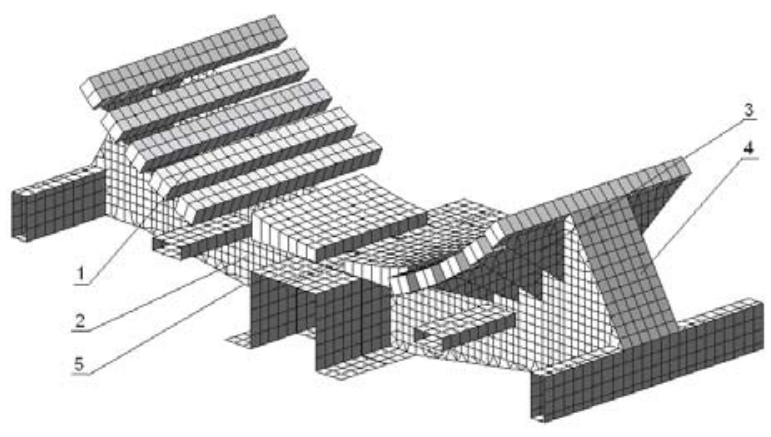

Рис. 2. Схема консольного опорного пристрою (варіант 1):

1 - опорний елемент; 2 - діафрагма; 3 - ребро жорсткості; 4 - похилий лист

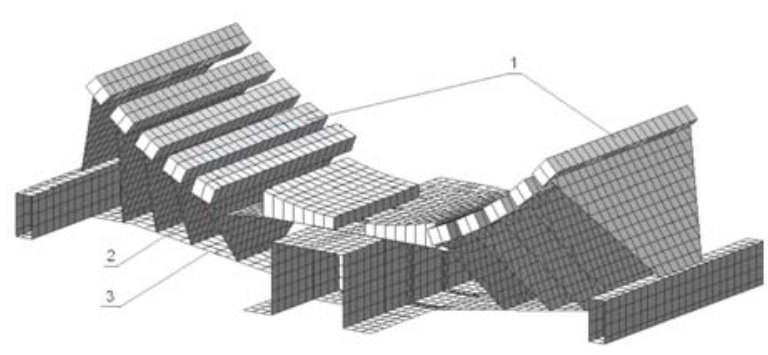

Рис. 3. Схема консольного опорного пристрою (варіант 2):

1 - опорні елементи; 2 - діафрагма; 3 - шкворневий лист

Відмінною особливістю перших двох варіантів $\epsilon$ відсутність чітко вираженої шкворневої балки. 


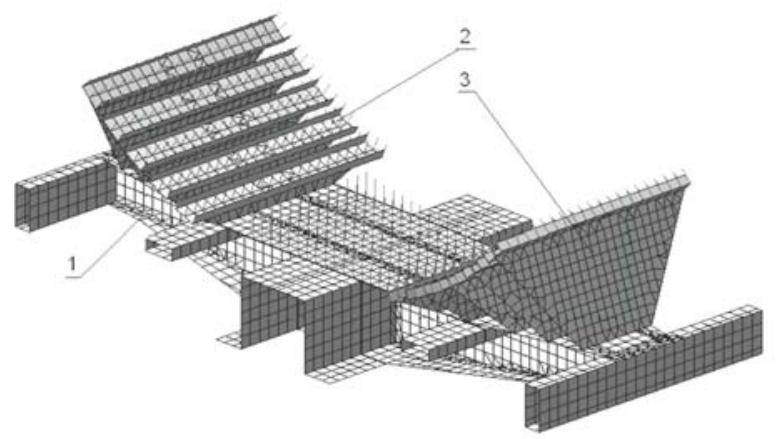

Рис. 4. Схема консольного опорного пристрою (варіант 3):

1 - шкворнева балка; 2 - опорний елемент; 3 - діафрагма

Третій варіант зображено на рис. 4. У ньому збережена шкворнева балка 1, а передача навантаження на неї від котла здійснюється через опорні елементи 2 і подовжні діафрагми 3, що підкріплюють їх. Між собою діафрагми з'єднуються стержневими елементами.

У другому і третьому варіантах підкріплюючі подовжні діафрагми виконано у вигляді листів трапецієвидного контуру. Для зниження

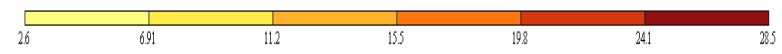

a)

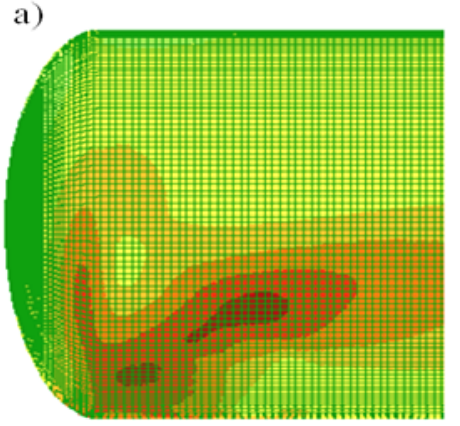

жорсткості уздовж середньої поверхні листа вони виконані з гофрами.

Розрахунок цистерн 3 різними конструктивними виконаннями консольних опор здійснювався на один вид статичного навантаження сумісна дія ваги рідини і власної ваги конструкції. Результати розрахунку відображаються у вигляді полів еквівалентних напружень, розрахованих за енергетичною теорією міцності.

Порівняння отриманих розрахункових даних здійснювалося 3 конструкцією рамної цистерни, що використовується на сьогодні.

В ході аналізу результатів розрахунків було виявлено, що для першого варіанта максимальні напруження в опорній зоні склали 28,5 МПа, що на $15 \%$ менше порівняно 3 існуючою конструкцією. Також має місце зменшення площі дії максимальних напружень (рис. 5).

За результатами обчислень для другого і третього варіантів виявлено, що значення максимального еквівалентного напруження зменшується на $13 \%$ (рис. 6).
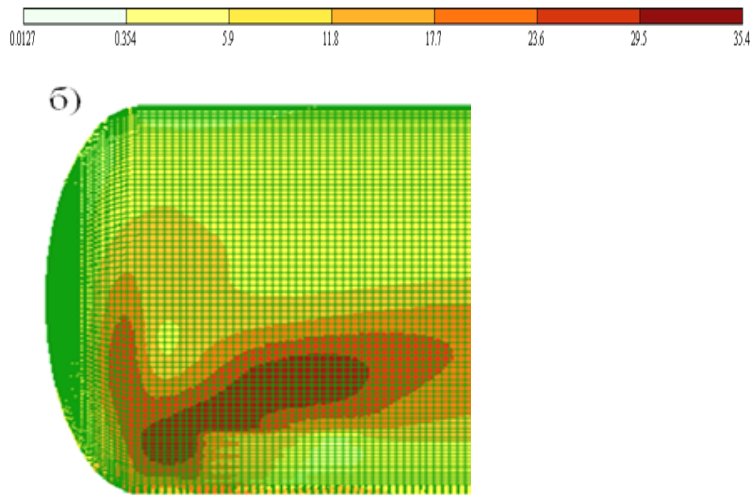

Рис. 5. Еквівалентні напруження від дії ваги брутто конструкції: $a$ - запропонована конструкція (варіант 1 ); $\sigma$ - існуюча конструкція

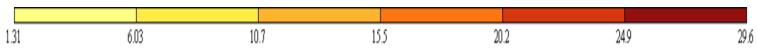

a)

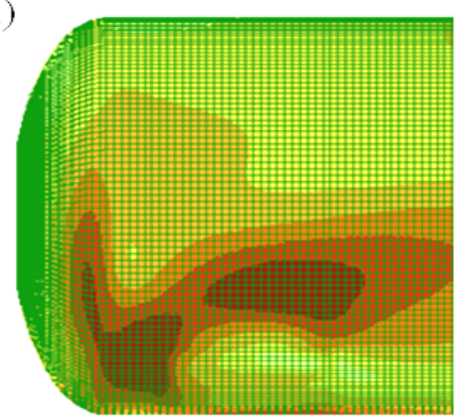

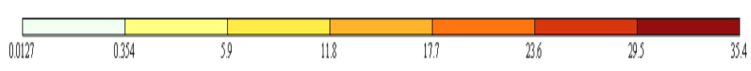

6)

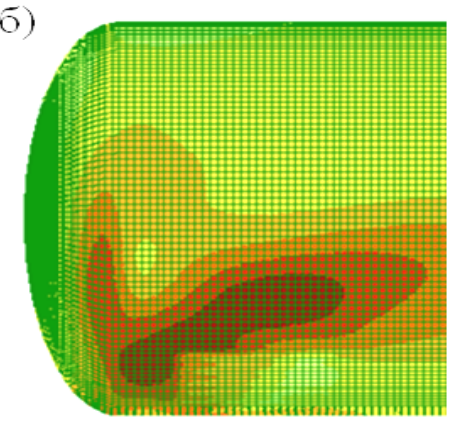

Рис. 6. Еквівалентні напруження від дії ваги брутто конструкції: $a$ - запропонована конструкція (варіант 3 ); $\sigma$ - існуюча конструкція 
Виконані розрахунки опорних пристроїв дозволяють зробити висновок, що виходячи із значень еквівалентних напружень найбільш ефективнішим $є$ перший варіант [14], для нього функція мети та обмеження має вигляд: удар в цистерні при екстремальному значенні поздовжньої сили 3,5 МН. Допустимі напруження в рамі та котлі цистерни для I розрахункового режиму складають $[\sigma]=0,9 \sigma_{T}=265,5$ МПа.

$$
\begin{aligned}
& m^{\text {проп }}(\bar{X}) \rightarrow \min \\
& \bar{X} \in Д_{\mathrm{x}} \in \text { Д }
\end{aligned}
$$

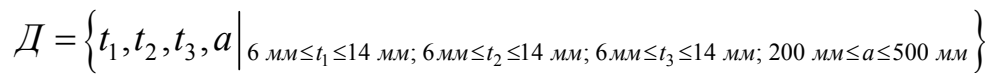

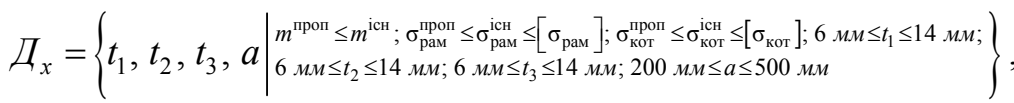

де Д - область можливих рішень, яка формується границями варіювання складових вектора змінних параметрів $\bar{X}$; Д - область допустимих рішень; $m^{\text {iсн }}$ - маса сучасної конструкції опорного пристрою чотиривісної залізничної цистерни; $t_{1}, t_{2}, t_{3}$ - товщини вертикальної діафрагми, нижнього та торцевого листів відповідно; $a$ - ширина запропонованої конструкції уздовж твірної котла цистерни; $\sigma_{\text {рам }}^{\text {проп }} \sigma_{\text {кот }}^{\text {проп }}$ максимальні еквівалентні напруження, які виникають в опорі та опорній зоні котла запропонованої конструкції; $\sigma_{\text {рам }}^{\text {iсн }}, \sigma_{\text {кот }}^{\text {iсн }}-$ максимальні еквівалентні напруження, які виникають в опоpi та опорній зоні котла існуючої конструкції; $\left[\sigma_{\text {рам }}\right],\left[\sigma_{\text {кот }}\right]$ - допустимі напруження в рамі та котлі цистерни.

Для дослідження НДС конструкції з різними геометричними розмірами прийняті такі навантаження: вага брутто вагона 3 урахуванням коефіцієнта вертикальної динаміки; гідравлічний
3 урахуванням вихідних даних (2) складається математичний план, який має відповідну матрицю планування. На іiї основі складається ортогональний математичний план другого порядку для чотирьох керованих змінних, що варіюються на трьох рівнях $[3,4,8,17,19,20]$.

Для кожного режиму математичного плану 3 використанням розрахункової моделі вагонацистерни обчислюються значення показників, що контролюються - маса опорного пристрою, що пропонується $m^{\text {проп }}$, максимальні еквівалентні напруження, які виникають в опорі та опорній зоні котла нової конструкції - $\sigma_{\text {рам }}^{\text {проп }}, \sigma_{\text {кот }}^{\text {проп }}$. 3 використанням отриманих значень $m^{\text {проп }}$, $\sigma_{\text {рам }}^{\text {проп }}, \sigma_{\text {кот }}^{\text {проп }}$ виконується їх апроксимація у вигляді поліномів другого ступеня.

Нижче наведено узагальнені математичні моделі для контрольованих показників у дійсних величинах змінних:

$$
\begin{array}{r}
m^{\text {проп }}=0,026+30315,15 t_{1}-3282,85 t_{2}+11,566 t_{3}+0,455 a-96661,109 t_{1}^{2}+ \\
+98763,982 t_{2}^{2}-1143,356 t_{3}^{2}-1,547 a^{2}-929,864 t_{1} t_{2}-1719,577 t_{1} t_{3}- \\
-2601,336 t_{1} a+1459,122 t_{2} t_{3}+21759,325 t_{2} a-11001,238 t_{3} a \\
\sigma_{m^{\text {проп }}}= \pm 28,3 \mathrm{\kappa} ; \\
\sigma_{\text {рам }}^{\text {проп }}=2445,633-32106,203 t_{1}+14160,405 t_{2}-343557,841 t_{3}-528,629 a-1893377,319 t_{1}^{2}- \\
-931753,335 t_{2}^{2}+1313209324 t_{3}^{2}-834,011 a^{2}-2445828,413 t_{1} t_{2}+522987,688 t_{1} t_{3}+ \\
+40050,0 t_{1} a+359903,70 t_{2} t_{3}+60560,647 t_{2} a+10833,942 t_{3} a
\end{array}
$$




$$
\begin{gathered}
\sigma_{\sigma_{\text {орам }}^{\text {проп }}}= \pm 17,7 \mathrm{M \Pi а} ; \\
\sigma_{\text {кот }}^{\text {проп }}=81,464+2948,819 t_{1}-2984,917 t_{2}+1790,687 t_{3}+100,661 a+2556,003 t_{1}^{2}+ \\
+24780,923 t_{2}^{2}-20093,994 t_{3}^{2}-137,495 a^{2}+16967,531 t_{1} t_{2}-64729,459 t_{1} t_{3}- \\
-5238,180 t_{1} a-34549,856 t_{2} t_{3}+5401,132 t_{2} a-552,842 t_{3} a \\
\sigma_{\sigma_{\text {когт }}^{\text {проп }}}= \pm 7,5 \mathrm{M \Pi а.}
\end{gathered}
$$

Величини середньоквадратичних відхилень для отриманих узагальнених математичних моделей свідчать про їх адекватність і придатність для використання в подальших дослідженнях 3 визначення геометричних параметрів опорного пристрою вагона-цистерни.

Для розв'язання задачі оптимізації (5) використовувався метод Нелдера-Міда. Ідея методу полягає у порівнянні значень функції в $n+1$ вершинах симплексу та переміщенні точок симплексу у напрямку оптимальної точки за допомогою ітераційної процедури [5].

Спочатку, при різних початкових значеннях параметрів, проводилась оптимізація всіх чотирьох параметрів. При цьому перші два параметри змінювалися, даючи різні значення функції, що мінімізується, а $t_{3}$ та $a$ залишалися практично незмінними: $t_{3}=0,01$ м, $a=0,3$ м. Це дало можливість при фіксованих значеннях $x_{3}$ та $x_{4}$ звести задачу до оптимізації двох параметрів $x_{1}$ та $x_{2}$. 3 точністю до $3 \%$ отримані значення $t_{1}=0,0114 \mathrm{M}, t_{2}=0,0094 \mathrm{M}$, при цьому $m^{\text {проп }}=405$ кг; $\sigma_{\text {рам }}^{\text {проп }}=260 \mathrm{MПа;} \sigma_{\text {кот }}^{\text {проп }}=110$ МПа.

При відомих значеннях двох параметрів $t_{3}$ та $a$ для оптимізації $t_{1}$ та $t_{2}$ можна скористатися графічним методом. Для цього за допомогою отриманих апроксимацій були обчислені функ-

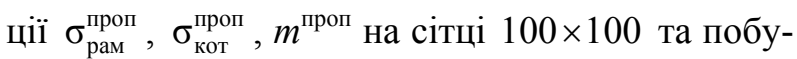
довані ізолінії цих функцій (рис. 7).

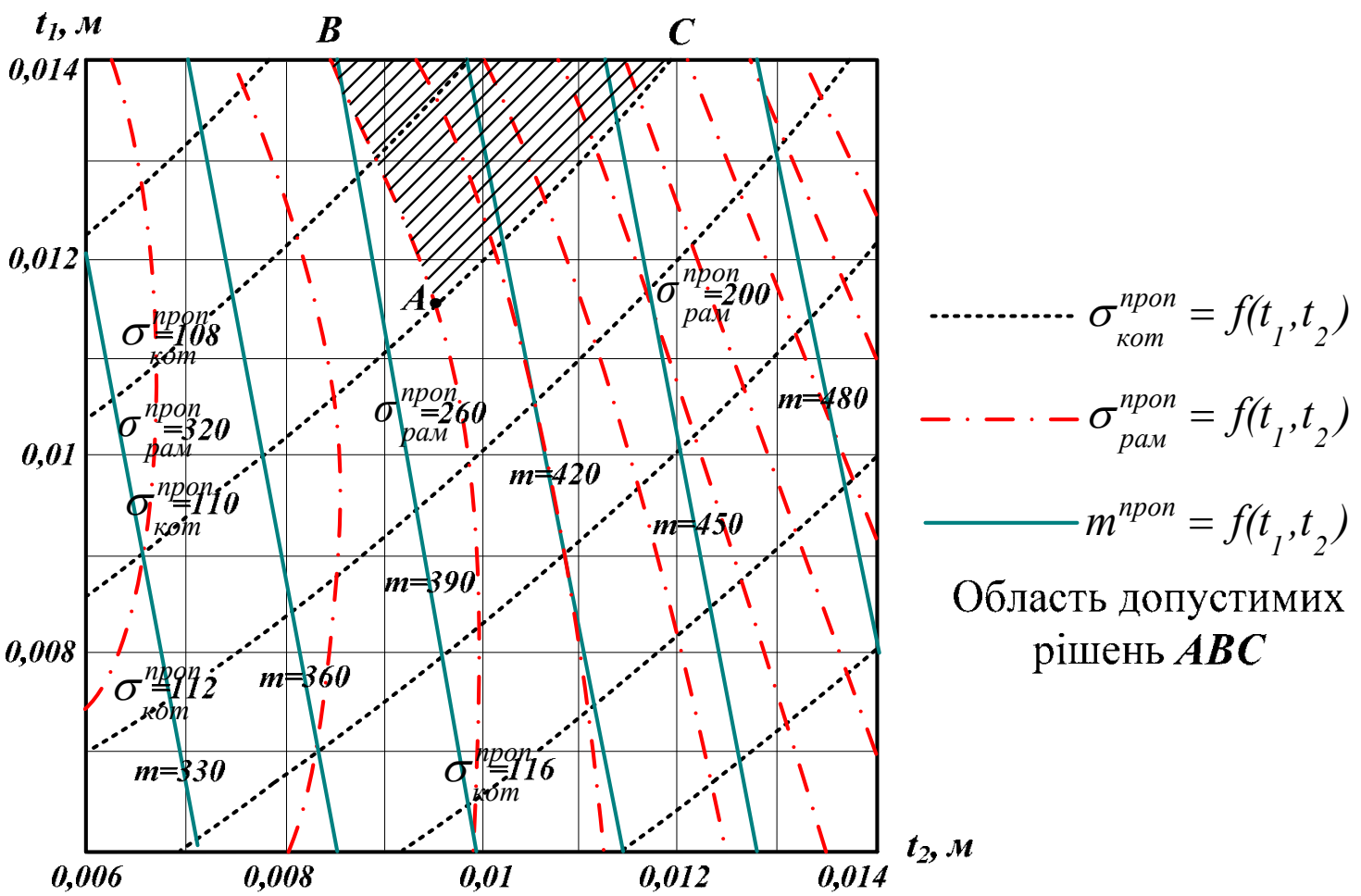

Рис. 7. Графік визначення оптимальних параметрів конструкції опорного пристрою вагона-цистерни 
Аналізуючи графік (див. рис. 7) видно, що оптимальними $\epsilon$ параметри в точці $\mathrm{A}$ : $t_{1}=0,0116 \mathrm{м}$ та $t_{2}=0,0095$ м. Пошук, що здійснювався в області допустимих рішень Дх, дав можливість як оптимальні визначити такі величини параметрів: $t_{1}=12 \mathrm{mm;} t_{2}=10$ мм. Таке рішення обгрунтовується встановленими ГОСТ 19903-74 нормативними значеннями листового прокату ( $\delta=4$ мм; 4,5 мм; 5 мм; 6 мм; 7 мм; 8 мм; 9 мм; 10 мм; 12 мм ...) і технологічними особливостями виготовлення опорного пристрою вагона-цистерни. Як видно, результати оптимізації, які отримані двома способами, дуже близькі. При більшій кількості змінних зручніше користуватися числовим методом.

Маса конструкції опорного пристрою при оптимальних значеннях $t_{1}=12 \mathrm{MM}, t_{2}=10 \mathrm{MM}$, $t_{3}=10 \mathrm{мм}, a=0,3$ м становить $m^{\text {проп }}=415 \mathrm{\kappa}$, що на $13 \%$ менше порівняно з існуючою конструкцією.

\section{Результати}

Серед запропонованих варіантів конструктивних рішень консольних опорних пристроїв котла вагона-цистерни найбільш ефективним $€$ перший варіант. Знайдені оптимальні геометричні розміри складових цієї конструкції.

\section{Наукова новизна та практична значимість}

Запропоновані нові конструктивні рішення консольних опорних пристроїв котла цистерни. Чисельно досліджено вплив нової конструкції на НДС вагона-цистерни.

Виконано математичний опис задачі оптимізаційного проектування за критерієм мінімальної матеріалоємності опорного пристрою вагона-цистерни та використано його для удосконалення конструкції.

Для вирішення задачі оптимізаційного проектування за критерієм мінімальної матеріалоємності опорного пристрою вагона-цистерни використано чисельний та графічний методи.

\section{Висновки}

1. Проаналізовано особливості розвитку конструктивних схем вітчизняних і зарубіжних цистерн, виконано патентно-бібліографічний аналіз технічних рішень опорних пристроїв, виявлено переваги і недоліки. Обгрунтовано напрямки удосконалення конструкції опорного пристрою цистерни.

2. Розроблено розрахункові скінченноелементні моделі вагона-цистерни 3 різними конструктивними виконаннями консольних опорних пристроїв, які дали змогу оцінити НДС конструкції.

3. За результатами розрахунків виявлено, що запропоновані варіанти є досить ефективними, оскільки знижуються максимальні напруження в оболонці котла цистерни. В першому варіанті на половину зменшується площа дії максимальних напружень. В двох інших - напруження приблизно рівномірно розподіляються навколо опори. У варіантах 2 і 3 підкріплюючі діафрагми $є$ дуже жорсткими, тому необхідно на них встановлювати пружні елементи, які будуть сприймати все навантаження від котла. Також можна використовувати гофри в конструктивному виконанні цих діафрагм для зниження жорсткості.

\section{СПИСОК ВИКОРИСТАНИХ ДЖЕРЕЛ}

1. Беспалько, С. В. Оценка влияния параметров днища на напряженное состояние котла цистерны / С. В. Беспалько, В. И. Богачев // Наука та прогрес трансп. Вісн. Дніпропетр. нац. ун-ту залізн. трансп. - 2013. - № 1 (43). - С. 133-138.

2. Вагон - цистерна для бензина других светлых нефтепродуктов, модель 15-1443-06. Котел. Расчет на прочность, 1443.01.000 - 11 РР6. Отчет ГСКТИ СКБ ВС, 2002 г. - 31 с.

3. Винарский, М. С. Планирование эксперимента в технологических исследованиях / М. С. Винарский, М. В. Лурье. - К. : Техника, 1975. $168 \mathrm{c.}$

4. Ермаков, С. М. Математическая теория оптимального эксперимента / С. М. Ермаков, А. А. Жиглявский. - М. : Наука, 1987. - 320 с.

5. Ермуратский, П. В. Симплексный метод оптимизации / П. В. Ермуратский // Труды МЭИ. М., 1967. - Вып. 67. - С. 29.

6. Ждамаров, В. С. Исследование напряженного состояния оболочки котла железнодорожной цистерны от локальных нагрузок : автореф. дис. ... канд. техн. наук : 05.05.01 / Владимир Степанович Ждамаров ; МИИТ. - М., 1980. $23 \mathrm{c.}$

7. Исследования по изысканию новых конструктивных схем четырехосных вагонов-цистерн с целью снижения их металлоемкости : отчет о 
НИР (заключ.) / Всесоюз. науч.-исслед. ин-т вагоностроения (НИИВ) ; рук. Лагута В. С. Кременчуг, 1985. - Ч. І. - 63 с. № ГР 01840013267. - Инв. № 02850060917.

8. Костриця, С. А. Оптимизация несущей конструкции планировщика балластной призмы CП3-5/UA / С. А. Костриця, Б. М. Товт // Наука та прогрес трансп. Вісн. Дніпропетр. нац. ун-ту залізн. трансп. - 2013. - № 2 (44). - С. 106-117.

9. Лагута, В. С. Анализ конструктивных вариантов вагонов-цистерн. Развитие конструкций вагонов. Анализ результатов испытаний и эксплуатации / В. С. Лагута, А. В. Донченко, Ю. Я. Водянников // Сб. науч. тр. НИИвагоностроения. - 1988. - С. 58-64.

10. Нерубайло, Б. В. Локальные задачи прочности цилиндрических оболочек / Б. В. Нерубайло. М. : Машиностроение, 1983. - 248 с.

11. Павлюченков, М. В. Дослідження конструктивних варіантів опор залізничних цистерн для перевезення рідких вантажів / М. В. Павлюченков // Пробл. та перспективи розв. залізн. трансп. : тез. доп. 70 Міжнар. наук.-практ. конф. / ДНУЗТ. - Д., 2010. - С. 81-82.

12. Павлюченков, М. В. Информационные технологии расчета и проектирования вагонацистерны на статические и ударные нагрузки / М. В. Павлюченков // Інформ.-керуючі системи на залізн. трансп. : наук.-техн. журн. - 2010. № 3. - С. 30-36.

13. Павлюченков, М. В. Комп'ютерна модель вагона-цистерни / М. В. Павлюченков // Рухомий склад з-ць та госп-во : зб. наук. пр. / УкрДАЗТ. - Х., 2008. - Вип. 86. - С. 111-117.
14. Пат. 72134 Україна, МПК В 61 D 5/06. Пристрій для кріплення котла залізничної цистерни на рамі ходової частини / Павлюченков М. В. ; заявник та патентовласник Українська державна академія залізничного транспорту. № u2012 00495 ; заявл. 16.01.2012 ; опубл. 10.08.12, Бюл. № 15. -4 с.

15. Статистическая информация о повреждениях железнодорожных нефтебензиновых цистерн обработка с помощью СУБД MS ACCESS / МИИТ. - М., 1998. - 24 с.: ил. - Деп. в ЦНИИТЭИ МПС, 03.03.98, № 6153 жд-98.

16. Эксплуатационные повреждения нефтебензиновых железнодорожных цистерн - фотоснимки, схемы / МИИТ. - М., 1998. - 55 с.: ил. - Деп. в ЦНИИТЭИ МПС, 03.03.98, № 6154 жд-98.

17. Floudas, C. A. Encyclopedia of Optimization / C. A. Floudas, P. M. Pardalos. - New York : Springer Science, 2009. - 4246 p.

18. Glasers Annalen. - 2000. - № 7. - P. 415-417.

19. Mohd, R. S. Generalized railway tank car safety design optimization for hazardous materials transport: Addressing the trade-off between transportation efficiency and safety / R. S. Mohd, Barkan P. L. Christopher // J. of Hazardous Materials. 2011. - Vol. 189. - Iss. 1-2, 15. - P. 62-68.

20. Rozvany, G. I. N. Aims, scope, methods, history and unified terminology of computer-aided topology optimization in structural mechanics / G. I. N. Rozvany // Structural and Multidisciplinary Optimization. - 2001. - № 21. - P. 90-108.

\section{М. В. ПАВЛЮЧЕНКОВ ${ }^{1 *}$}

\footnotetext{
${ }^{1 *}$ Каф. «Строительная механика и гидравлика», Украинская государственная академия железнодорожного транспорта, пл. Фейербаха, 7, Харьков, Украина, 61500, тел. +38 (057) 73010 70, эл. почта misha_83@ukr.net
}

\section{РАЦИОНАЛИЗАЦИЯ КОНСТРУКЦИИ ОПОРНЫХ УСТРОЙСТВ ВАГОНОВ-ЦИСТЕРН ДЛЯ ЖИДКИХ ГРУЗОВ}

Цель. Усовершенствование конструкции вагонов-цистерн для перевозки жидких грузов за счет новых технических решений консольных опорных устройств и снижения их материалоемкости. Методика. Для решения поставленной задачи выполнены исследования для поиска оптимальной конструкции опорного устройства. На первом этапе выполнен патентно-библиографический анализ технических решений, выявлены преимущества и недостатки конструкций, а также предложены новые их варианты; определена наиболее эффективная конструкция среди них. На следующем этапе для определения ее оптимальных параметров составлена функция цели, введены ограничения; получена аппроксимация функций цели и ограничений в виде полиномов. На третьем этапе предложена численная реализация оптимизации функции и определены оптимальные параметры конструкции графическим методом. Результаты методов совпали. Результаты. Среди предложенных вариантов определена наиболее эффективная конструкция опорного устройства, получены его оптимальные геометрические размеры. Научная новизна. Выполнено математическое описание задачи оптимизационного проектирования по критерию минимальной материалоемкости опорного устройства вагона-

(C) М. В. Павлюченков, 2014 
цистерны и использовано для усовершенствования конструкции. Для решения задачи оптимизационного проектирования использованы численный и графический методы. Практическая значимость. Разработаны расчетные конечно-элементные модели вагона-цистерны с различными конструктивными исполнениями консольных опорных устройств, которые позволили оценить НДС конструкции.

Ключевые слова: вагоны-цистерны; котел; консольное опорное устройство; грузоподъемность; подкрепляющий элемент; эквивалентное напряжение; функция цели; обобщенная математическая модель

\section{V. PAVLIUCHENKOV ${ }^{1^{*}}$}

${ }^{1 *}$ Dep. «Building Mechanic and Hydraulic», Ukrainian State Academy of Railway Transport, Feuerbach Sq., 7, Kharkiv, Ukraine, 61500, tel.+38(057) 73010 70, e-mailmisha_83@ukr.net

\section{STRUCTURE RATIONALIZATION OF TANK CARS SUPPORT DE- VICES FOR FLUIDS}

Purpose. Improvement of fluid tank cars structure due to development of new tank bracket support structures and their materials consumption decrease. Methodology. The investigations to search the optimal design of the support structure were conducted in order to solve such problem. At the first stage patent and bibliographic analysis of technical solutions was done, the advantages and disadvantages were revealed and new design options were proposed, the most efficient design was determined. The next step is objective function making for determining its optimal parameters, imposition of restrictions, acquisition of objective function approximation and restrictions in the form of polynomials. At the third stage numerical implementation of function optimization was proposed, optimal design parameters were determined with graphical method. Results methods have coincided. Findings. The most efficient design of support structure was determined; its optimum geometrical dimensions were described. Originality. The author provides the mathematical formulation of optimal design of tank car supports using the minimum materials consumption criteria. The graphic and numerical methods were used during the investigations. Practical value. The author proposed the finite-element models of tank car with different design execution of bracket support structures, which allow estimating the VAT of structure.

Keywords: tanks cars; barrel; bracket support structure; vehicle capacity; supporting element; reduced stress; objective function; generic mathematical model

\section{REFERENCES}

1. Bespalko S.V., Bogachev V.I. Otsenka vliyaniya parametrov dnischa na napryazhennoye sostoyaniye kotla tsisterny [Assessment of the influence of the parameters bottom of the stress state of the boiler of the tank]. Nauka ta prohres transportu. Visnyk Dnipropetrovskoho natsionalnoho universytetu zaliznychnoho transportu - Science and Transport Progress. Bulletin of Dnipropetrovsk National University of Railway Transport, 2013, no. 1 (43), pp. 133-138.

2. Vagon - tsisterna dlya benzina drugikh svetlykh nefteproduktov, model 15-1443-06. Kotel. Raschet na prochnost, 443.01.000 - 11 RR6. Otchet GSKTI SKB VS [Car-petrol tank for other light petroleum products, model 15-1443-06. The boiler. Strength calculation, 1443.01.000 - 11 RR6. Report GSKTI SKB VS], 2002, 31 p.

3. Vinarskiy M.S., Lure M.V. Planirovaniye eksperimenta v tekhnologicheskikh issledovaniyakh [Planning of experiment in technological research]. Kiev, Tekhnika Publ., 1975. 168 p.

4. Yermakov S.M., Zhiglyavskiy A.A. Matematicheskaya teoriya optimalnogo eksperimenta [Mathematical theory of optimal experiment]. Moscow, Nauka Publ., 1987. 320 p.

5. Yermuratskiy P.V. Simpleksnyy metod optimizatsii [The simplex method of optimization]. Trudy MEIMPEI Proceedings, 1967, issue 67, p. 29.

6. Zhdamarov V.S. Issledovaniye napryazhennogo sostoyaniya obolochki kotla zheleznodorozhnoy tsisterny ot lokalnykh nagruzok. Avtoreferat Diss. [Investigation of stress state of the shell of boiler of a tank wagon here local loads. Author's abstract]. Moscow, 1980. 23 p.

7. Issledovaniya po izyskaniyu novykh konstruktivnykh skhem chetyrekhosnykh vagonov-tsistern s tselyu snizheniya ikh metalloemkosti [Research to find new constructive schemes of four-axle tank cars to reduce metal consumption]. Kremenchug, VNIIV Publ., 1985. Part I. 63 p.

8. Kostritsa S.A., Tovt B.M. Optimizatsiya nesushchey konstruktsii planirovshchika ballastnoy prizmy SPZ-5/UA [Optimization of the bearing structure of the scheduler points-local prism SP3-5/UA]. Nauka ta

(C) М. В. Павлюченков, 2014 
prohres transportu. Visnyk Dnipropetrovskoho natsionalnoho universytetu zaliznychnoho transportu - Science and Transport Progress. Bulletin of Dnipropetrovsk National University of Railway Transport, 2013, no. 2 (44), pp. 106-117.

9. Laguta V.S., Donchenko A.V., Vodyannikov Yu.Ya. Analiz konstruktivnykh variantov vagonov-tsistern. Razvitiye konstruktsiy vagonov. Analiz rezultatov ispytaniy i ekspluatatsii [Analysis of structural variants of tank-wagons. The development of the designs of the cars. Analysis of the results of tests and operation]. Sbornik nauchnykh trudov nauchno-issledovatelskogo instituta vagonostroeniya [Proc. of Scientific and Research Institute of Cars Construction]. Kremenchug, 1988, pp. 58-64.

10. Nerubaylo B.V. Lokalnyye zadachi prochnosti tsilindricheskikh obolochek [Local tasks strength of cylindrical shells]. Moscow, Mashinostroeniye Publ., 1983. 248 p.

11. Pavliuchenkov M.V. Doslidzhennia konstruktyvnykh variantiv opor zaliznychnykh tsystern dlia perevezennia ridkykh vantazhiv [Research of structural variants supports rail tank cars for transportation of liquid cargoes]. Tezy dopovidei 70 mizhnarodnoi naukovo praktychnoi konferentsii «Problemy ta perspektyvy rozvytku zaliznychnoho transportu» [Proc. of the $70^{\text {th }}$ Int. Sci. and Practical Conf. «Problems and prospects of railway transport development»]. Dnipropetrovsk. 2010, pp. 81-82.

12. Pavliuchenkov M.V Informatsionnyye tekhnologii rascheta i proyektirovaniya vagona-tsisterny na staticheskiye i udarnyye nagruzki [Information technology calculation and design of tank wagons for static and shock loads]. Informatsiino-keruiuchi systemy na zaliznomu transporti - Information and control systems at railway transport, 2010, issue 3, pp. 30-36.

13. Pavliuchenkov M.V. Kompiuterna model vahona-tsysterny [Computer model of a tank wagon]. Zbirnyk naukovykh prats «Rukhomyi sklad zaliznyts ta hospodarstvo» [Proc. «Rolling stock of Railways and economy»]. Kharkiv, 2008, issue 86, pp. 111-117.

14. Pavliuchenkov M. V. Prystrii dlia kriplennia kotla zaliznychnoi tsysterny na rami khodovoi chastyny [Device for fastening of the railway tanks boiler on the frame chassis]. Patent UA, no. 2012 00495, 2012. 4 p.

15. Statisticheskaya informatsiya o povrezhdeniyakh zheleznodorozhnykh neftebenzinovykh tsistern - obrabotka s pomoshchyu SUBD MS ACCESS [Statistical information on damage of rail tanks - processing using MS ACCESS]. Moscow, MIIT Publ., 1998. 24 p.

16. Ekspluatatsionnyye povrezhdeniya neftebenzinovykh zheleznodorozhnykh tsistern - fotosnimki, skhemy [Operational damages of rail tanks - photo-pictures, schemes]. Moscow, MIIT Publ., 1998. 55 p.

17. Floudas C.A., Pardalos P.M. Encyclopedia of Optimization. New York, Springer Science, 2009. 4246 p.

18. Glasers Annalen, 2000, no. 7, pp. 415-417.

19. Mohd Rapik Saat, Christopher P.L. Barkan. Generalized railway tank car safety design optimization for hazardous materials transport: Addressing the trade-off between transportation efficiency and safety. Journal of Hazardous Materials, 2011, vol. 189, issues 1-2, 15, pp. 62-68.

20. Rozvany G.I.N. Aims, scope, methods, history and unified terminology of computer-aided topology optimization in structural mechanics. Structural and Multidisciplinary Optimization, 2001, no. 21, pp. 90-108.

Стаття рекомендована до публикаиії д.т.н., проф. О. М. Даренським (Україна); д.т.н., проф. С. В. Мямліним (Украӥна)

Надійшла до редколегії 11.11.2013

Прийнята до друку 14.01.2014 